Egyptian Journal of Rabbit Science, 28 (2): 351-370 (2018)

\title{
REPRODUCTIVE AND PHYSIOLOGICAL RESPONSE OF NEW ZEALAND WHITE RABBIT DOES FED ON DISCARDED PALM FRONDS.
}

Walaa A. Salama* and Enayat H. Abo El-Azayem

Animal Production Research Institute, Agricultural Research Center, -Dokki,

Giza, Egypt.

*Corresponding author: E-mail: Address: walaa.attia2@gmail.com

This study carried out to determine the effects of substitution 25 and $50 \%$ of clover hay with discarded palm fronds (DPF) or biologically treated discarded palm fronds (Bio-DPF) in does diet on reproductive, physiological response and economic efficiency of New Zealand White (NZW) rabbit does. Twenty five New Zealand White (NZW) does aged 5 months weighting $3140 \pm 26.55 \mathrm{~g}$ were randomly distributed into 5 experimental treatments (5 does/ treatment). Experimental diets were as follows: diet 1: A control without substitution, while in the other diets contained 5 and $10 \%$ untreated and treated discarded palm fronds with Effective microorganisms $\left(E M_{1}\right)$ to substitute 25 and $50 \%$ of clover hay of control diet.

Results could be summarized as follows: Biological treatments was improved chemical composition of DPF which mainly CP content was markedly increased but $C F$ was decreased. Inclusion of Bio-DPF in does diet affected significantly both daily feed intake and change in weight of does during gestation and suckling period compared with other treatments. Diets with Bio-DPF significantly $(P \leq 0.05)$ achieved the best figures for litter size of and weights from birth up to weaning that in turn revealed significant $(P \leq 0.05)$ decreased in mortality rate (\%) as compared to group fed diet contain 50\% DPF. Feeding the does on diets contained Bio-DPF significantly $(P \leq 0.05)$ produced the highest milk yield.

Data showed significantly increased in total protein and globulin with Bio-DPF. However, there were significantly decrease in the value of plasma cholesterol and total lipids for rabbits fed on 50\%DPF and Bio-DPF. 6- It can be noticed that rabbits fed on the diets contained Bio-DPF had the best economic return compared to other treatments. 
Conclusively, it could be recommended to incorporate Bio-DPF of the rabbit doe diets to replace up to 50\% of clover hay improve their reproductive, physiological traits and improve economic efficiency.

Keywords: Discarded palm fronds, rabbits, biologically, reproductive, physiological.

Female reproduction is an interesting and attractive subject to study and preferred by many researchers as it is essential, important and beneficial for successful rabbits breeding. Litter size, birth weight and conception rate are so important economic traits in any productive animals. For great profit a special attention must be focused on these traits, so studying factors directly affecting them are so important and must be taken into consideration during breeding of any productive species (Mahmoud, 2013).Feeding cost is the most expensive item in animal production cycle and reached about $70 \%$ from the total cost of rabbit industry (EL-Sayaad, 2002). Rabbit's nutritionists are looking for developing feeding strategies capable of reducing digestive diseases and high mortality rate while enhancing body condition of reproducing does, therefore increasing their reproductive performances and increasing feed efficiency so lowering feeding and total production costs (Maertens, 2009). Data of fruit production yields several crop residues, including date palm leaves (fronds), inedible dates, date pits, pinne of date palm and mid rib of date palm are not utilized for human consumption. Several experiments by different investigators revealed that date stone meal could be included in rabbit diets (El- Manylawi and El-Banna, 2013).

Discarded palm fronds are poor in nutritive value for animals owing to their low protein, high fiber content and low palatability which limits their use in livestock feeding. To improve digestibility of these agricultural wastes, it is important to breakdown the linkages among cellulose, hemicelluloses and lignin by biological treatments. Recently, several works using biological treatments to improve nutritive value of by products by using $\mathrm{EM}_{1}$ has been recommended as feed additives for poultry and ruminants to reduce heat stress, improving feed conversion and dressing percentage or working as a manipulating agent for agricultural by- products (Higa, 2002). $\mathrm{EM}_{1}$ is a product of EMRO Organization in Japan (EM ${ }_{1}$ Research Organization, Inc., Takamiyagi Bldg. 2F, 2-9-2 Gameko, Ginowan-shi Okinawa, Japan. EM $_{1}$ is a combination of 70 to 80 different types of "good" and beneficial microorganisms contributing to the wide range of applications. The principal 
organisms of are usually five; photosynthetic bacteria (phototrophic bacteria), lactic acid bacteria, yeasts, actinomycets and fermenting fungi (Higa, 1993). Abdel-Aziz et al., (2014) found that biological treatments are paralleled with decreased crude fiber and fiber fractions content with increased crude protein content. In animal nutrition El-Tahan et al., (2013) found that lambs fed ration $60 \%$ or $50 \%$ of the allowances from concentrate feed mixture +treated palm fronds grinded with plureuerotus ostreatus by apparel to higher live body weight than those fed ration allowances from concentrate feed mixture + palm fronds grinded and no significant differences in daily feed intake, weight gain and feed conversion. Moreover, Ali et al., (2017) found replacing 15\% or 30\% of berseem hay by biological treated conocarpus with fungi (Trichoderma reesi) or effective microorganisms $\left(\mathrm{EM}_{1}\right)$ in Baladi Black rabbit does diets, resulted in improve their reproduction performance without any adverse effect on physiological responses with high profitability under Egyptian conditions.

Therefore, the objectives of the present study were to investigate the effects of dietary inclusion of untreated or biologically treated discarded palm fronds by effective microorganisms $\left(\mathrm{EM}_{1}\right)$ on reproductive, physiological traits and feed cost of rabbit does.

\section{MATERIALS AND METHODS}

The experimental work of this study carried out at Poultry Research Station, in Kafr EL- Sheikh Governorate, Animal Production Research Institute, Agricultural Research center .The biological treatment, analysis of samples and discarded palm fronds were carried out at the Laboratories of ByProducts Research Department, Animal Production Research Institute. Discarded palm fronds were obtained from Luxor governorate, Egypt. The EM is a product of EMRO Organization in Japan ( $\mathrm{EM}_{1}$ Research Organization, Inc., Takamiyagi Bldg. 2F, 2-9-2 Gameko, Ginowan-shi Okinawa, Japan). $\mathbf{E M}_{1}$ is a combination of 70 to 80 different types of "good" and beneficial microorganisms contributing to the wide range of applications. The principal organisms of are usually five; photosynthetic bacteria (phototrophic bacteria), lactic acid bacteria, yeasts, actinomycets and fermenting fungi (Higa, 1993).

\section{Preparation of palm fronds}

Palm fronds from each crop residue were sun dried until complete drying and five ground to pass through $0.1 \mathrm{~mm}$ screen was soaked in tab water until moisture content reached to $60-70 \%$ followed by soaking in boiled water for 2 
hours according to Balasubramanya and Kathe (1996) to decrease contamination.

\section{Biological treatment}

Hundred kilo grams of Palm fronds were cooled to room temperature and until moisture reached 65-70\%,then 5\% $\mathrm{EM}_{1}$ and 5\% El-mofeed were dissolved in $90 \mathrm{~L}$ of water and mixed with Palm fronds under air condition and package into polyethylene bags and left for three weeks (Shahin et al., 2012).

\section{Treatments and Animals}

Twenty five New Zealand White (NZW) does at 5 months of age with average weight $3140 \pm 26.55 \mathrm{~g}$ were housed separately in individual wiredcages. Mating was achieved by 5 adult New Zealand White bucks aged 6 months with good fertility records. Bucks were fed on control diet. All rabbits were kept under the same managerial and hygienic conditions and housed in metal battery cages supplied with separated feeders. Diets were offered $a d$ libitum and fresh water was available all times from automatic nipple drinkers.

Five experimental diets were formulated, including the control diet without discarded palm fronds while, the other tested diets have discarded palm fronds (DPF) and biologically treated discarded palm fronds (Bio-DPF) at 25 or $50 \%$ replacement of clover hay 5.00 or $10.00 \%$ in basal diet as shown in Table 1. The ingredients of diets formulation and its chemical composition are presented in Table 1. All the experimental diets were formulated according to (Agriculture Ministry Decree, 1996). The digestible energy (DE kcal $/ \mathrm{kg}$ ) of discarded palm fronds and clover hay were calculated according to the equation of Cheek (1987). Neutral detergent fibre (NDF), acid detergent fibre (ADF) and detergent lignin (ADL) were determined by method of Van Socest (1982).

\section{Reproductive performance}

For does, the change in live body weight during gestation period was calculated as the difference between the live body weight at kindling and body weight post-partum, while the change in live body weight during suckling was calculated as the difference between the live body weight at the end of suckling period (at weaning) (28 days post-partum) and the body weight post-partum. Suckling kids were allowed to eat the same diet as their mother and were weaned at 35days of age. Lactating rabbit does (five / group) were used to measure milk production. Rabbit does were separated from their kids after 
parturition and controlled suckling was applied. To prevent free nursing, does were placed in cages next to the nest box. Litter sizes (LS) of kits were kept constant throughout lactation. Milk production was estimated daily from weight loss of rabbit does after suckling (Mohamed et al., 2016).Milk production was assessed at $7^{\text {th }}, 14^{\text {th }}, 21^{\text {st }}$ and $28^{\text {th }}$ day of lactation. Kids were separated from their mothers to prevent suckling for a period of 24 hours before samples collection in the morning. Body weight and weight gain of kids were measured at birth and at weaning. Mortality rate (MR) during lactation for kids was calculated as:

$$
\text { MR of kids }=\frac{\text { Number of the kids born alive - Number of the kids at weaning }}{\text { Number of the kids born alive }} \times 100
$$

\section{Blood measurement}

Individual blood samples were taken at 9.00 am from the marginal ear vein and collected in $5 \mathrm{ml}$. heparinized test tubes and centrifuged at 3000 r.p.m for 20 minutes then plasma were transferred and stored in deep freezer at approximately $-20^{\circ} \mathrm{C}$ till the time to determine total protein (Gornal et al., 1949), albumin (Doumas and Waston, 1971), transaminase (AST, aspartate aminotransferase and ALT, alanine aminotransferase), Reitman and Frankel (1957), total lipids (Zollner and Kirsch, 1962), total cholesterol (Richmond, 1973), creatinine (Schirmeister, 1964) and urea (Fawcett and Scott, 1960).

\section{Economic efficiency}

The economic efficiency of experimental diets was calculated as the ratio between net revenue and cost of feed consumed according to Soliman et al., (2012).

\section{Statistical analysis}

Data from all response variables were analysed using General Linear Models (GLM) procedure of SAS Institute (2004). The statistical model used was as follows:

$$
Y i j=\mu+T i+e i j
$$

Where: $\mu=$ Overall mean of Yij, $\mathrm{Ti}=$ Effect of treatment, $\mathrm{i}=(1, \ldots, 5)$, eij $=$ Experimental random error.

Variables having a significant F-test were compared using Duncan's multiple range test (Duncan, 1955). 
Table 1.Ingredients and chemical composition of experimental diets.

\begin{tabular}{|c|c|c|c|c|c|}
\hline \multirow{2}{*}{ Ingredients } & \multirow{2}{*}{ Control } & \multicolumn{2}{|c|}{ DPF } & \multicolumn{2}{|c|}{ Bio-DPF } \\
\hline & & $25 \%$ & $50 \%$ & $25 \%$ & $50 \%$ \\
\hline Soybean meal (44\% CP) & 24.50 & 24.50 & 25.30 & 24.50 & 25.30 \\
\hline Barely grain & 23.00 & 23.00 & 22.00 & 23.00 & 22.00 \\
\hline Clover hay & 20.00 & 15.00 & 10.00 & 15.00 & 10.00 \\
\hline DPF & ---------- & 5.00 & 10.00 & ------- & ------- \\
\hline Bio-DPF & -------- & ------ & ------- & 5.00 & 10.00 \\
\hline Yellow corn & 15.00 & 15.00 & 15.00 & 15.00 & 15.00 \\
\hline Wheat bran & 10.49 & 10.19 & 10.20 & 10.19 & 10.20 \\
\hline Molasses & 3.00 & 3.00 & 3.00 & 3.00 & 3.00 \\
\hline Di calcium phosphate & 2.37 & 2.67 & 2.86 & 2.67 & 2.86 \\
\hline Lime stone & 0.70 & 0.70 & 0.70 & 0.70 & 0.70 \\
\hline DL-Methionine & 0.34 & 0.34 & 0.34 & 0.34 & 0.34 \\
\hline Sodium Chloride $(\mathrm{NaCl})$ & 0.30 & 0.30 & 0.30 & 0.30 & 0.30 \\
\hline Premix* & 0.25 & 0.25 & 0.25 & 0.25 & 0.25 \\
\hline Anticoccidia(Diclazuril) & 0.05 & 0.05 & 0.05 & 0.05 & 0.05 \\
\hline Total & 100 & 100 & 100 & 100 & 100 \\
\hline \multicolumn{6}{|l|}{ Calculated analysis\% ${ }^{I}$} \\
\hline OM\% & 89.79 & 89.57 & 89.35 & 88.70 & 88.45 \\
\hline $\mathrm{CP} \%$ & 18.84 & 18.39 & 18.25 & 18.47 & 18.38 \\
\hline $\mathrm{CF} \%$ & 10.43 & 10.92 & 11.42 & 10.72 & 11.04 \\
\hline $\mathrm{EE} \%$ & 2.23 & 2.16 & 2.08 & 2.17 & 2.12 \\
\hline NFE\% & 58.29 & 58.10 & 57.60 & 57.34 & 56.91 \\
\hline Ash\% & 10.21 & 10.43 & 10.65 & 11.30 & 11.55 \\
\hline $\mathrm{DE}(\mathrm{kcal} / \mathrm{kg})$ & 2688.8 & 2677.2 & 2665.2 & 2680.6 & 2675.8 \\
\hline Calcium & 1.21 & 1.20 & 1.21 & 1.23 & 1.22 \\
\hline Total phosphorus & 0.84 & 0.87 & 0.91 & 0.88 & 0.91 \\
\hline Methonine & 0.62 & 0.61 & 0.61 & 0.61 & 0.61 \\
\hline \multicolumn{6}{|c|}{ 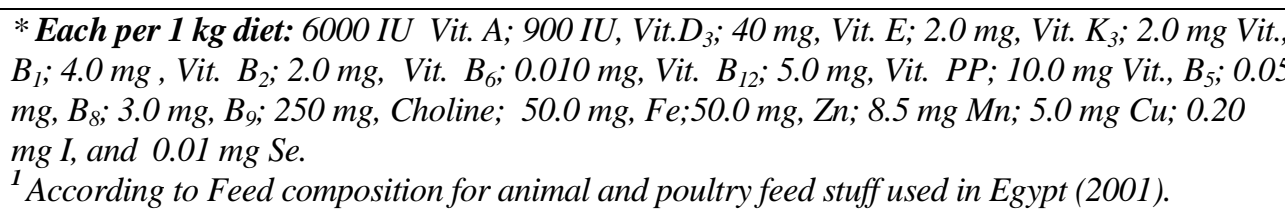 } \\
\hline
\end{tabular}

\section{RESULTS AND DISCUSSION}

Chemical composition of DPF and Bio-DPF compared to clover hay.

As shown in Table (2), chemical analysis of DPF and Bio-DPF compared with clover hay revealed that CP $(3.68,5.47 v s .12 .00 \%), \mathrm{CF}(40.21,36.34 v s$. 31.00), DE (1648.8, 1768.01 vs. $1972.2 \mathrm{~K} \mathrm{cal} / \mathrm{kg})$, EE (0.85, 1.20 vs. $2.10 \%)$, 
Table 2. Chemical analysis of DPF and Bio-DPF compared to clover hay on DM basis.

\begin{tabular}{lccc}
\hline Items & DPF & Bio-DPF & Clover hay \\
\hline DM\% & \multicolumn{1}{c}{89.03} & 89.74 & 83.62 \\
Chemical analysis\% & (on DM basis) & & \\
OM\% & 94.13 & 92.97 & 88.94 \\
CP\% & 3.68 & 5.47 & 12.00 \\
CF\% & 40.21 & 36.34 & 30.00 \\
EE\% & 0.85 & 1.20 & 2.10 \\
NFE\% & 49.39 & 49.96 & 44.84 \\
Ash\% & 5.87 & 7.03 & 11.06 \\
DE(kcal/kg)* & 1648.8 & 1768.01 & 1972.2 \\
Cell wall constituents: & 65.21 & 59.23 & 55.11 \\
NDF & 41.30 & 31.54 & 42.00 \\
ADF & 8.54 & 8.03 & 18.43 \\
ADL & 23.91 & 27.69 & 13.11 \\
Hemicellulose & 32.76 & 23.51 & 23.57 \\
Cellulose & & & \\
\hline
\end{tabular}

DPF: discarded palm fronds , Bio-DPF: Biologically treated discarded palm fronds.

$* \mathrm{DE}(\mathrm{kcal} / \mathrm{g})=4.36-0.0491 \mathrm{x} \mathrm{NDF}$, Where NDF\% $=28.924+0.657 \mathrm{x}$ CF\% (according to Cheeke, 1987).

NDF: Neutral detergent fiber, ADF: Acid detergent fiber, ADL: Acid detergent Lignin

Hemi cellulose: NDF-ADF; Cellulose: ADF-ADL.

NFE content (49.38, 49.96 vs. 44.84\%), NDF (65.21, 59.23 vs. 55.11\%), ADF (41.30, 31.54 vs. $42.00 \%)$, ADL (8.54, 8.03 vs. 18.43\%). Hemi cellulose (23.91, 27.69vs. 13.11\%) and cellulose (32.76, 23.51vs. 23.57).The chemical composition of untreated discarded palm fronds has similar trend that reported by El- Tahan et al., (2013) found that palm fronds grinded content $3.25 \% \mathrm{CP}$, 42.14\% CF, 0.77\% EE, 69.35\% NDF, 42.92\% ADF and 10.61\% ADL.Also ElBordeny and Abdel-Azeem (2007) found that palm tree leaves content 7.02\% CP, $0.96 \%$ EE, $28.21 \% \mathrm{CF}, 54.02 \% \mathrm{NFE}$ and $9.80 \%$ Ash. Ibrahim et al., (2013) found that mid ribe of data palm contained $2.69 \% \mathrm{CP}, 34.95 \% \mathrm{CF}$, $2.98 \%$ EE, $41.70 \%$ NFE, $4.31 \%$ ADL, $43.47 \%$ ADF and 57.82\%NDF.This result is confirmed by Villas-Boas et al., (2002) who reported that biological treatment is used for increasing the nutritional value of many by-products because they have significant concentrations of simple carbohydrates such as mono and disaccharides. While, crude fibre content was reduced because microorganisms depend on this material as carbon source for growth and 
formation the microbial protein. Increasing ash content may be attributed to the growth or degradation of organic matter of discarded palm fronds by microorganism. Reduction in NFE could be related to the consumption of carbohydrates by the microorganism as energy sources for their growth and multiplication. Abdel-Aziz et al., (2014) who found that biological treatments are paralleled with decreased crude fibre and fibre fractions content with increased crude protein content.

\section{Performance of rabbit does during gestation period}

Results of the effect of DPF and Bio-DPF on the performance of does during gestation period are presented in Table (3). The gestation length, total feed intake, mating weight and gestation weight haven't significantly affected by different treatments. Inclusion of Bio-DPF in does diet affected significantly both daily feed intake and change in weight of does during gestation period compared with other treatments. The does fed 25 and 50\% Bio-DPF diets were recorded the highest feed intake value 5.6077 and $5.395 \mathrm{~kg}$, respectively. The does fed on 25 and 50\% Bio-DPF during gestation period were recorded the highest change in weight $+138.67 \mathrm{~g}$ and $+31.33 \mathrm{~g}$, respectively. On the other hand, feed intake did not differ significantly with fed on DPF diets compared to control diet and also change in weight did not differ significantly with fed on 25 $\%$ DPF does during gestation period. However, change in weight during gestation period significantly decreased with fed on 50\% DPF diets as compared with other treatments.

The regular increase in body weight at this phase could be due to the active growth of the embryos at this stage. These results revealed that does can tolerate using Bio-DPF up to 50\% substitution for clover hay during the gestation period (30 days) without adverse effects. In this respect, Ali et al.,( 2017) reported that replacing $15 \%$ and $30 \%$ of berseem hay by biological treated conocarpus with $\mathrm{EM}_{1}$ in rabbit does diet resulted in significantly $(\mathrm{P} \leq$ 0.05) had higher weights for pregnancy and consumed more feed intake than those fed the other untreated diets. These results agree with Xiccato et al., (2004) who reported increasing in BW, FI and milk production of rabbit does with using balanced fibrous dietary diets. That, diets included balanced nutrients composition especially in the domain of fibrous components gave a highest performance possible in term of production or feed efficiency (Gidenne, 2000; Fortun-Lamothe and Gidenne, 2003). 
Table (3). Performance traits of rabbit does as affected by feeding DPF or BioDPF during gestation period.

\begin{tabular}{|l|c|c|c|c|c|c|c|}
\hline \multirow{2}{*}{ Items } & Control & \multicolumn{2}{|c|}{ DPF, \% } & \multicolumn{2}{c|}{ Bio-DPF, \% } & SEM & Sig. \\
\cline { 3 - 7 } & & $\mathbf{2 5}$ & $\mathbf{5 0}$ & $\mathbf{2 5}$ & $\mathbf{5 0}$ & & \\
\hline $\begin{array}{l}\text { Gestation length } \\
\text { (days) }\end{array}$ & 30.66 & 30.33 & 30.33 & 30.00 & 30.00 & 0.33 & NS \\
\hline $\begin{array}{l}\text { Total feed intake } \\
\text { ( kg/doe) }\end{array}$ & 4.387 & 4.637 & 4.4320 & 5.6077 & 5.395 & 0.13 & NS \\
\hline $\begin{array}{l}\text { Daily feed intake } \\
\text { (kg/doe) }\end{array}$ & $143.10^{\mathrm{b}}$ & $154.09^{\mathrm{b}}$ & $147.73^{\mathrm{b}}$ & $186.92^{\mathrm{a}}$ & $177.87^{\mathrm{a}}$ & 4.87 & $* *$ \\
\hline $\begin{array}{l}* \text { Mating weight } \\
\text { (g) doe }\end{array}$ & 3166.6 & 3155.0 & 3136.67 & 3125.0 & 3116.67 & 26.55 & NS \\
\hline $\begin{array}{l}* * \text { Gestation } \\
\text { weight (g) doe }\end{array}$ & 3286.33 & 3277.3 & 3251.00 & 3263.67 & 3248.33 & 13.91 & NS \\
\hline $\begin{array}{l}* * * \text { Change in } \\
\text { weight (g) }\end{array}$ & $119.73^{\mathrm{b}}$ & $122.33^{\mathrm{b}}$ & $114.33^{\mathrm{c}}$ & $138.67^{\mathrm{a}}$ & $131.33^{\mathrm{a}}$ & 2.46 & $* *$ \\
\hline
\end{tabular}

DPF: discarded palm fronds ,Bio-DPF: Biologically treated discarded palm fronds.

$a, b$-- Means in the same row with different superscripts are significantly different $(P<0.05)$.

NS: Not significant, $\quad * *:(P<0.01)$.

*Mating weight $(g)$ doe is live body weight at post partum.

**Gestation weight $(g)$ doe is live body weight at kindling.

***Change in weight $(g)=$ Gestation weight $(g)$ - Mating weight $(g)$.

\section{Performance of rabbit does during suckling period}

Results in Table (4) indicated that total feed intake, mating weight and, suckling weight were not significantly affected by the different treatments However, daily feed intake and change in weight of the doe were significantly affected by the different experimental treatments. Also, mean values of daily feed intake during suckling period showed significant increase for does fed diets containing 25\%Bio-DPFcompared with the DPF. However, daily feed intake showed no significant differ for does fed diets containing 50\%Bio-DPF and DPF compared with control group. On the other hand, change weight with does fed Bio-DPF highest more change weight-135.7gand-139.10compared with the control group. Although, change weight with does fed 50\% DPF lowest more change weight. However, Inclusion DPF at level 25\% for does not significant differ in change weight compared with control group and other does fed Bio-DPF. These results were in agreement with Ali et al., (2017) who found that improvement in rabbit does performance in lactation period and increased feed intake when rabbits fed diets contained treated conocarpus with fungus or $\mathrm{EM}_{1}$ 
Table (4).Performance of rabbit does as affected by feeding DPF or Bio-DPF during suckling period.

\begin{tabular}{|l|c|c|c|c|c|c|c|}
\hline \multirow{2}{*}{ Items } & \multirow{2}{*}{ Control } & \multicolumn{2}{|c|}{ DPF, \% } & \multicolumn{2}{c|}{ Bio-DPF, \% } & SEM & Sig. \\
\cline { 3 - 7 } & & $\mathbf{2 5}$ & $\mathbf{5 0}$ & $\mathbf{2 5}$ & $\mathbf{5 0}$ & & \\
\hline $\begin{array}{l}\text { Total feed intake } \\
\text { ( kg/doe) }\end{array}$ & 6.4967 & 6.3967 & 6.2400 & 6.7367 & 6.5067 & 0.11 & $\mathrm{NS}$ \\
\hline $\begin{array}{l}\text { Daily feed intake } \\
\text { (kg/doe) }\end{array}$ & $232.03^{\mathrm{ab}}$ & $228.42^{\mathrm{b}}$ & $222.80^{\mathrm{b}}$ & $240.57^{\mathrm{a}}$ & $232.35^{\mathrm{ab}}$ & 2.04 & $* *$ \\
\hline $\begin{array}{l}\text { *Mating weight }(\mathbf{g}) \\
\text { doe }\end{array}$ & 3166.60 & 3116.67 & 3136.67 & 3125.00 & 3155.00 & 26.55 & $\mathrm{NS}$ \\
\hline $\begin{array}{l}* \text { Suckling weight }(\mathbf{g}) \\
\text { doe }\end{array}$ & 3060.50 & 3000.00 & 3069.1 & 2989.00 & 3015.90 & 31.28 & $\mathrm{NS}$ \\
\hline **Change in weight $(\mathbf{g})$ & $-106.1^{\mathrm{b}}$ & $-116.67^{\mathrm{ab}}$ & $-67.57^{\mathrm{c}}$ & $-135.7^{\mathrm{a}}$ & $-139.10^{\mathrm{a}}$ & 7.39 & $* *$ \\
\hline
\end{tabular}

DPF: discarded palm fronds ,Bio-DPF: Biologically treated discarded palm fronds.

$a, b---$ Means in the same row with different superscripts are significantly different $(P<0.05)$..

NS: Not significant and $* *:(P<0.01)$.

*Mating weight $(g)$ doe is live body weight at post partum.

**Suckling weight $)(g)$ doe is live body weight at the end of suckling period.

$* * *$ Change in weight $(g)=$ Suckling weight $(g)$ - Mating weight $(g)$.

\section{Productive traits of kids}

Productive traits of kids as affected by different experimental treatments are presented in Table (5). Inclusion of Bio-DPF in doe diets significantly increased litter size at birth (total alive), weaning, litter weight at birth, litter weight at weaning, total litter gain, kid weight at birth and daily weight gain of kid compared with group fed diet contain 50\% DPF. Although, litter size at birth, weaning, litter weight at birth and kid weight at birth litter weight at weaning, total litter gain and daily weight gain of kid not significantly affected by the different treatments with does fed DPF as compared to control group except daily weight gain of kids insignificantly increased with $25 \%$ DPF compared with rabbits fed 50\% DPF. Although, litter weight at weaning, total litter gain were significantly decreased with does fed 50\% DPF compared with other treatments. However, kids weight at weaning and total weight gain of kid were not affected by different treatments. Diets with Bio-DPF significantly ( $\mathrm{P} \leq$ $0.05)$ achieved the best figures for litter size of and weights from birth up to weaning that in turn revealed significant $(\mathrm{P} \leq 0.05)$ decreased in mortality rate $(\%)$ as compared to group fed diet contain $50 \%$ DPF. However, mortality rate $(\%)$ were significant $(\mathrm{P} \leq 0.05)$ increased with doe fed 50\% DPF compared with the rest of experimental treatments. Ali et al., (2017) found that rabbits fed 
Table (5).Productive traits of kids as affected by feeding DPF or Bio-DPF.

\begin{tabular}{|c|c|c|c|c|c|c|c|}
\hline \multirow{3}{*}{$\begin{array}{l}\text { Items } \\
\begin{array}{l}\text { Litter size at birth } \\
\text { (total born) }\end{array}\end{array}$} & \multirow{3}{*}{$\begin{array}{c}\text { Control } \\
7.33\end{array}$} & \multicolumn{2}{|c|}{ DPF, \% } & \multicolumn{2}{|c|}{ Bio-DPF, \% } & \multirow{3}{*}{$\begin{array}{l}\text { SEM } \\
0.33\end{array}$} & \multirow{3}{*}{$\begin{array}{l}\text { Sig } \\
\text { NS }\end{array}$} \\
\hline & & \multicolumn{2}{|r|}{50} & \multicolumn{2}{|l|}{25} & & \\
\hline & & 7.33 & 6.09 & 8.33 & 8.00 & & \\
\hline $\begin{array}{l}\text { Litter size at birth } \\
\text { (total alive) }\end{array}$ & $6.39^{\mathrm{ab}}$ & $6.40^{\mathrm{ab}}$ & $5.84^{\mathrm{b}}$ & $7.16^{\mathrm{a}}$ & $7.24^{\mathrm{a}}$ & 0.20 & $* *$ \\
\hline $\begin{array}{l}\text { Litter size at } \\
\text { weaning }\end{array}$ & $5.52^{\mathrm{a}}$ & $5.27^{\mathrm{ab}}$ & $4.32^{\mathrm{b}}$ & $6.27^{\mathrm{a}}$ & $6.16^{\mathrm{a}}$ & 0.22 & $* *$ \\
\hline $\begin{array}{l}\text { Litter weight } \\
\text { at birth (g) }\end{array}$ & $412^{\mathrm{ab}}$ & $403^{b}$ & $340^{b}$ & $540^{\mathrm{a}}$ & $538^{\mathrm{a}}$ & 25.99 & $* *$ \\
\hline $\begin{array}{l}\text { Litter weight at } \\
\text { weaning (g) }\end{array}$ & $2500^{\mathrm{b}}$ & $2499^{b}$ & $1861.92^{\mathrm{c}}$ & $3135^{\mathrm{a}}$ & $2983^{\mathrm{ab}}$ & 138.1 & $*$ \\
\hline $\begin{array}{l}\text { Total litter gain } \\
\text { (kg)/doe }\end{array}$ & $2.143^{\mathrm{b}}$ & $2.096^{\mathrm{b}}$ & $1.521^{\mathrm{c}}$ & $2.594^{\mathrm{a}}$ & $2.445^{\mathrm{a}}$ & 0.10 & $* *$ \\
\hline $\begin{array}{l}\text { Kid weight at birth } \\
\text { (g) }\end{array}$ & $64.47^{\mathrm{ab}}$ & $62.96^{\mathrm{ab}}$ & $58.33^{\mathrm{b}}$ & $75.41^{\mathrm{a}}$ & $74.30^{\mathrm{a}}$ & 2.39 & $* *$ \\
\hline $\begin{array}{l}\text { Kid weight at } \\
\text { weaning (g) ( } 28 \text { day) }\end{array}$ & 452.89 & 474.19 & 431.00 & 500.00 & 484.25 & 10.31 & NS \\
\hline $\begin{array}{l}\text { Total weight gain of } \\
\text { kid (g) }\end{array}$ & 388.42 & 411.23 & 372.67 & 424.59 & 409.9 & 13.11 & NS \\
\hline $\begin{array}{l}\text { Daily weight gain of } \\
\text { kid (g) }\end{array}$ & $13.87^{\mathrm{ab}}$ & $14.68^{\mathrm{a}}$ & $13.31^{\mathrm{b}}$ & $15.16^{\mathrm{a}}$ & $14.63^{\mathrm{a}}$ & 6.30 & $* *$ \\
\hline $\begin{array}{l}\text { Mortality\% of kids } \\
\text { [from birth (total } \\
\text { alive till weaning) }\end{array}$ & $13.61^{\mathrm{b}}$ & $17.65^{\mathrm{b}}$ & $26.02^{\mathrm{a}}$ & $12.43^{\mathrm{b}}$ & $14.91^{\mathrm{b}}$ & 1.60 & $* *$ \\
\hline
\end{tabular}

DPF:discarded palm fronds , Bio-DPF: Biologically treated discarded palm fronds.

$a, b$--- Means in the same row with different superscripts are significantly different $(P<0.05)$.

NS: Not significant, $\quad * *:(P<0.01)$.

conocarpus + EM1 and with 15 or $30 \%$ conocarpus with Trichodermareesi significantly $(\mathrm{P} \leq 0.05)$ increased litter size and weights from birth up to weaning and significantly $(\mathrm{P} \leq 0.05)$ increased litter daily weight gains. Additionally, large litter size post-reported that the effects may evoke great tactile stimulation of teats and indirectly enhance milk secretion through increased prolactin release (Lukefahret al., 1983).Also, these results has discussed by Szendroet al., (2002) who reported that the milk production available per kid may be have a pronounced effect on the mortality of young rabbits. Besides that, decrease of mortality rate may be reflecting an increase of milk quality with treated diets by biological treatments. Moreover decreasing in mortality rate for young rabbits belong to treated groups during suckling period 
may be due to increase milk yield (Table 4). Drummond et al., (2000) found that rabbit kids with high birth weight was grew faster and weight level increased stable over the 3 weeks. The obtained improvement of the growth performance and the milk production with groups fed Bio-DPF might be due to the decreasing of anti nutritional factors (cellulose and hemi cellulose) and biologically treated palm fronds grinded was high content of exogenous enzymes, amino acids, and other secondary metabolites, like vitamins as a result of microorganism activity in diets contained Bio-DPF which improved the growth performance and the milk production.

\section{Effect of dietary treatments on milk yield}

Results presented in Table (6) showed that the effect of DPF and BioDPF on milk yield. Does fed dietary inclusion of Bio-DPF recorded significantly the highest milk yield during four weeks of lactation compared with the other groups. However, the does fed higher included level 50\% DPF recorded great depression in milk yield during the four weeks period. The mean value of milk yield during four weeks showed the same trend as weekly recorded values of milk yield.

This improvement may be due to that does in those treatments consumed insignificantly the highest feed intake during suckling period which reflected on milk yield. These results are agreement with Ali et al., (2017) found that feeding the rabbit does on diets contained $15 \%$ conocarpus + EM1 and with 15 or $30 \%$ conocarpus with Trichodermareesi replacement of berseem hay significantly $(\mathrm{P} \leq 0.05)$ gave the highest milk yield. Al-Suwaiegh and Yousef (2017) found that goats fed 30\% urea treated palm leaves replacement of clover hay significantly higher in milk yield compared with other group. Gaafar et al., (2014) reported that during lactation, milk production was greater in does fed on fibrous dietary diets. Also, results confirm that generally, rabbit's milk yield showed gradual increase until $21^{\text {th }}$ day of lactation; afterwards it decreases by next 10 days (Lukefahr et al., 1983 and Chrastinova et al., 1997). Also, ELSayaad (1994) reported that the increasing in the litter size seemed to induce stimulation for mammary glands to produce high milk quantity. However, AboEl-Ezz et al., (1981) mentioned that inconsistent in milk yield increased by increasing the litter size.

Furthermore the obtained results of milk yield explained the highest loss in body weight for does fed Bio-DPF, whereas does produced the largest amount of milk yield lost more weight. 
Table 6. Effect of feeding DPF or Bio-DPF on milk yield of does (g/d).

\begin{tabular}{|l|c|c|c|c|c|c|c|}
\hline \multirow{2}{*}{ Items } & \multirow{2}{*}{ Control } & \multicolumn{2}{|c|}{ DPF, \% } & \multicolumn{2}{c|}{ Bio-DPF, \% } & SEM & Sig. \\
\cline { 3 - 7 } & & $\mathbf{2 5}$ & $\mathbf{5 0}$ & $\mathbf{2 5}$ & $\mathbf{5 0}$ & & \\
\hline \multirow{2}{*}{$\mathbf{1}^{\text {st }}$ week } & $75.21^{\mathrm{bc}}$ & $79.32^{\mathrm{b}}$ & $65.61^{\mathrm{c}}$ & $95.11^{\mathrm{a}}$ & $90.23^{\mathrm{a}}$ & 3.09 & $* *$ \\
\hline $\mathbf{2}^{\text {nd }}$ w eek & $119.11^{\mathrm{ab}}$ & $121.38^{\mathrm{ab}}$ & $98.76^{\mathrm{b}}$ & $139.31^{\mathrm{a}}$ & $136.70^{\mathrm{a}}$ & 4.82 & $* *$ \\
\hline $\mathbf{3}^{\text {rd }}$ week & $130.38^{\mathrm{b}}$ & $135.11^{\mathrm{ab}}$ & $114.62^{\mathrm{b}}$ & $151.43^{\mathrm{a}}$ & $149.00^{\mathrm{a}}$ & 4.82 & $* *$ \\
\hline $\mathbf{4}^{\text {th }}$ week & $121.12^{\mathrm{ab}}$ & $124.34^{\mathrm{ab}}$ & $100.60^{\mathrm{b}}$ & $135.32^{\mathrm{a}}$ & $133.11^{\mathrm{a}}$ & 4.86 & $* *$ \\
\hline Milk yield (g/d) & $111.45^{\mathrm{ab}}$ & $115.04^{\mathrm{ab}}$ & $94.89^{\mathrm{b}}$ & $130.29^{\mathrm{a}}$ & $127.26^{\mathrm{a}}$ & 3.59 & $* *$ \\
\hline
\end{tabular}

DPF:discarded palm fronds , Bio-DPF: Biologically treated discarded palm fronds.

$a, b$-- Means in the same row with different superscripts are significantly different $(P<0.05)$.

NS: Not significant, $* *:(P<0.01)$.

\section{Blood biochemical analysis}

As shown in Table 7, the recorded results showed that adding Bio-DPF to doe rabbit diets significantly increased concentrations of total protein compared to other treatments, and significantly increased concentrations of globulin with adding Bio-DPF and 25 DPF. Despite decreased albumen/globulin ratio with Bio-DPF and 25\% DPF compared to 50\% DPF group. These results indicated that inclusion Bio-DPF in does diet might be improve rabbit immunity and protein supply to milk production compared with other treatments. Adding the DPF and Bio-DPF to doe rabbits diet did not affect on the activities of AST, ALT enzymes, albumin, creatinine and urea compared to control group which suggest that those treatments haven't adverse effect on liver and kidney functions. Total cholesterol and total lipids were significantly affected by experimental treatments. However, total cholesterol and total lipids were not affected by using DPF but total lipids significantly decreased by using $25 \%$ BioDPF diet. In this respect, El-Bordeny and Abdel-Azeem (2007) found that replacing clover hay by palm tree leaves caused insignificant increase in serum total proteins and albumin concentrations compared to the control. El-Bordeny and Abdel-Azeem (2007) found rabbits group received a diet with $36 \%$ palm tree leaves recorded the lowest value $(\mathrm{P} \leq 0.05)$ of total lipids concentration compared to the other experimental groups which received 12 or $24 \%$ palm tree leaves. Also, they found insignificant differences were observed in total cholesterol and AST between the different experimental groups, control group recorded the highest value $(\mathrm{P} \leq 0.05)$ of ALT activity followed by the group received $24 \%$ then $36 \%$ palm tree leaves, while the lowest value was that of the 
Table 7. Effect of feeding DPF or Bio-DPF on blood biochemical analysis.

\begin{tabular}{|l|c|c|c|c|c|c|c|}
\hline \multirow{2}{*}{ Items } & \multirow{2}{*}{ Control } & \multicolumn{2}{|c|}{ DPF, \% } & \multicolumn{2}{c|}{ Bio-DPF, \% } & SEM & \multirow{2}{*}{ Sig. } \\
\cline { 3 - 6 } & & $\mathbf{2 5}$ & $\mathbf{5 0}$ & & \\
\hline Total protein (g/dl) & $4.14^{\mathrm{b}}$ & $4.42^{\mathrm{b}}$ & $3.97^{\mathrm{b}}$ & $5.72^{\mathrm{a}}$ & $5.28^{\mathrm{a}}$ & 0.26 & $* *$ \\
\hline Albumin (g/dl) & 2.25 & 2.47 & 2.16 & 2.74 & 2.63 & 0.09 & NS \\
\hline Globulin (g/dl) & $2.13^{\mathrm{c}}$ & $2.72^{\mathrm{b}}$ & $2.05^{\mathrm{c}}$ & $3.12^{\mathrm{a}}$ & $2.95^{\mathrm{ab}}$ & 0.11 & $* *$ \\
\hline $\begin{array}{l}\text { Albumin / } \\
\text { Globulin ratio }\end{array}$ & $0.92^{\mathrm{b}}$ & $0.90^{\mathrm{b}}$ & $1.05^{\mathrm{a}}$ & $0.87^{\mathrm{b}}$ & $0.89^{\mathrm{b}}$ & 0.02 & $*$ \\
\hline ALT(U/L) & 39.10 & 35.80 & 34.69 & 31.04 & 29.75 & 1.87 & NS \\
\hline AST(U/L) & 37.28 & 33.00 & 31.59 & 28.12 & 25.37 & 1.84 & NS \\
\hline $\begin{array}{l}\text { Total cholesterol, } \\
\text { mg/ dl }\end{array}$ & $333.00^{\mathrm{a}}$ & $324.04^{\mathrm{a}}$ & $276.21^{\mathrm{b}}$ & $317.40^{\mathrm{a}}$ & $263.67^{\mathrm{b}}$ & 8.59 & $* *$ \\
\hline $\begin{array}{l}\text { Creatinine, } \\
\text { mg/ dl }\end{array}$ & 1.59 & 1.53 & 1.29 & 1.35 & 1.25 & 0.05 & NS \\
\hline Urea-N, mg/ dl & 31.33 & 29.35 & 28.62 & 25.66 & 20.82 & 2.05 & NS \\
\hline Total Lipids (mg/dl & $184.33^{\mathrm{a}}$ & $170.00^{\mathrm{ab}}$ & $152.33^{\mathrm{bc}}$ & $162.73^{\mathrm{bc}}$ & $144.33^{\mathrm{c}}$ & 4.38 & $* *$ \\
\hline
\end{tabular}

DPF: Discarded palm fronds , Bio-DPF: Biologically treated discarded palm fronds.

$a, b$--- Means in the same row with different superscripts are significantly different $(P<0.05)$. NS: Not significant, $* *:(P<0.01)$ and $*:(P<0.05)$.

group received $12 \%$ palm tree leaves. Abd- El Ghany et al., (2016) found that cholesterol and total lipid were significantly $(\mathrm{P} \leq 0.05)$ lower in rabbits fed biologically conocarpus by $\mathrm{EM}_{1}$ as compared with untreated one.

\section{Economic efficiency}

The economic efficiency (\%) of the present experimental treatments was calculated based upon input-output analysis of the total feeding cost/doe and the prevailing selling price of the litter/doe at weaning (Table 8).

The present results indicate an increase of total and net relative revenue for rabbits fed on diets contained Bio-DPF compared to other treatments. it can be noticed that rabbits fed the diets contained 25 or 50\% Bio-DPF were achieved the highest economical efficiency (1.077 and 1.053) and relative economical efficiency (127.79 and 127.65) followed by rabbits fed 25\% DPF and the least was the rabbits fed 50\% DPF. These results are in harmony with those of Ali et al., (2017) who reported that replacing $15 \%$ and $30 \%$ of berseem hay by biological treated conocarpus with fungus or $\mathrm{EM}_{1}$ compared to those untreated in rabbit's does diet resulted in better economical efficiency (\%). 
Table (8). Effect of feeding DPF or Bio-DPF on economic efficiency.

\begin{tabular}{|c|c|c|c|c|c|}
\hline \multirow[t]{2}{*}{ Items } & \multirow[t]{2}{*}{ Control } & \multicolumn{2}{|c|}{ DPF, \% } & \multicolumn{2}{|c|}{ Bio-DPF, \% } \\
\hline & & 25 & 50 & 25 & 50 \\
\hline Price/kg diet & 4.50 & 4.41 & 4.42 & 4.21 & 4.24 \\
\hline $\begin{array}{l}\text { Total feed consumed doe/gestation } \\
\text { period/kg }\end{array}$ & 4.38 & 4.63 & 4.43 & 5.60 & 5.63 \\
\hline $\begin{array}{l}\text { Total feed consumed doe/suckling } \\
\text { period/kg }\end{array}$ & 6.49 & 6.39 & 6.24 & 6.73 & 6.50 \\
\hline Total feed cost /doe (LE) & 48.91 & 48.59 & 47.16 & 51.90 & 50.41 \\
\hline Litter size at weaning & 5.52 & 5.27 & 4.32 & 6.27 & 6.16 \\
\hline Total revenue/Litter at weaning $(\mathrm{LE})^{1}$ & 89.25 & 89.59 & 73.44 & 106.59 & 104.72 \\
\hline Net revenue/doe $(\mathrm{LE})^{2}$ & 40.34 & 41.00 & 26.28 & 54.69 & 54.31 \\
\hline Economical efficiency $(\mathrm{LE})^{3}$ & 0.824 & 0.8437 & 0.577 & 1.053 & 1.077 \\
\hline Relative economical efficiency & 100 & 102.39 & 67.62 & 127.79 & 127.65 \\
\hline
\end{tabular}

DPF: Discarded palm fronds , Bio-DPF: Biologically treated discarded palm fronds.

'Total revenue = Litter size 17 assuming that the selling price of each rabbit at weaning was 17 LE.

${ }^{2}$ Net revenue/ rabbit doe $(L E)=$ Total revenue/ Litter at weaning-Total feed cost / rabbit doe.

${ }^{3}$ Economic efficiency $=$ Net revenue/ rabbit doe/ Total feed cost $/$ rabbit doe $(L E)$.

Conclusively, it could be concluded from the present study that replacing 25 or $50 \%$ of clover hay by biological treated discarded palm fronds with effective microorganisms $\left(\mathrm{EM}_{1}\right)$ in rabbit does diets, resulted in improve their reproductive and physiological responses without any adverse effect.

\section{REFERENCES}

Abdel-Aziz Nahla, A.; Z.M.S. Abdel fattah; M.M. El-Adawy; L.M. Camacho; A.E. Kholif, M.Y. Elghandour Mona and B.E. Borhami. (2014). Biological treatments and feeding sugarcane bagasse in agriculture animals. An Overview.J. Integ. Agric. Adva., 8: 1-25.

Al-Suwaiegh, S.B. and A.Y. Al-Yousef (2017). Effect of feeding urea treated palm leaves on milk production, composition and animal performance of lactating Ardi goats. Asian Journal Of Animal Sci. ,11 (1); 14-22.

Abd- El Ghany, F.T.F., W.A.H. Ali, M.A. Mahmoud and L.F. AbdelMawla (2016).Effect of partial replacement of berseem hay by biologicaly treated. conocarpus on productive performance and physiological response of growing rabbits. The $9^{\text {th }}$ International Poultry Conference of the Egyptian Poultry Science Associatiation, 7-10 November, 2016, Hurgada, Egypt. 
Abo-El-Ezz, Z.Z., A. Hassan and M. Samak (1981).Effect of litters size and mating cycles on lactation in rabbits. Alex. J. Agric. Res., 29: 75-82.

Agriculture Ministry Decree (1996).The standard properties for ingredients, feed additives and feed manufactured for animal and poultry. El-Wakaee El-Masria (1997), No. 192. P. 95.Amirria Press Cairo, Egypt.

Ali ,W.A.H.;F. T. F Abd-El Ghany.;M.A. Mahmoud andL.F. AbdelMawla(2017).Effect of partial replacement of berseem hay with biologically treated conocarpus on reproductive performance of rabbits.Egyptian Journal of Rabbit Science, 27 (2): 289- 308.

Balasubramanya, R.H. and A.A. Kathe (1996). An inexpensive pre treatment of cellulosic materials for growing edible oyster mushrooms.BiorecourceTechnology, 57:303-305.

Biondi,D.; P.Cianci, C. Geraci, G. Ruberto and Piattelli (1993).Antimicrabial activity and chemical composition of essential oils from Sicilian aromatic plants.J.Flavour and Fragrance 8(6): 331-337.

Cheek, P.P. (1987).Rabbit Feeding and Nutrition.Orlando: Academic Press, Inc. Harcourt, Brace, Jovanovich, Publishers.

Chrastinova, L.; A.Sommer, J.Rafay and M.Svetlanska (1997).Avotan exploitation in rabbit nutrition. II. Nutrient digestibility and lactation performance of does rabbit. J. Farm Anim. Sci., 30: 80-86.

Doumas, B.T. and W. Waston (1971). Albumin standards and measurement of plasma albumin with bromocresol green. Clin. Chem. Acta., 31: 87.

Drummond, H. E.; Vazquez, S.; Sanchez-Colon, M.; Martinez-Gomez and R. Hudson (2000).Competition for milk in the domestic rabbit: Survivors benefit from littermate deaths. Ethol., 106: 511-526.

Duncan, D.B. (1955). Multiple range and multiple F. test. Biometrics, 11: 1-42.

El-Bordeny, N.E and F Abdel-Azeem (2007).Utilization of palm tree leaves in feeding growing rabbits. Egyptian, J. Nutrition and feeds 10 (2):275288.

El-Manylawi, M. A. and El-Banna, H. M. (2013). Effect of feeding date stone meal supplemented with allzyme ${ }^{\circledR}$ on performance of growth New Zealand rabbits. Egyptian J. Anim. Prod., 50(2):103-109.

El-Tahan, A.A.H.; T.F. Mohammadi; A.A. Bakr and A.A. Abu-El-Ella (2013). Upgrading Palm fronds through different treatments to be used as animal feed: 1- Using of biologically treated palm fronds grinded ted in sheep ration. Egyptian J. Nutrition and Feeds, 16 (2) 235-242. 
EL-Sayaad, G.A. (1994).A study on milk production of New Zealand White and Californian rabbits under Egyptian conditions. Egyptian J. Rabbit Sci., 4: 47-59.

EL-Sayaad, G.A. (2002).Newfeedstuffs resoureces in rabbit nutrition.Proc. $3{ }^{\text {th }}$ Sci.Conf.on rabbit Prod. in Hot Climates, 8-11 October Hugada, Egypt. pp: 461-467.

Fawcett, J.K. and J.E. Scott (1960).Determination of urea.J Clic. Path., 13:156-159.

Fortun-Lamothe, L., T. Gidenne (2003).Besoinsnutritionnels du lapereauetstratégiesd'alimentationautour du sevrage. INRA Prod. Anim., 16:39-47.

Gaafar, H.M.A., A.A. Ragab and K.F.A. El-Reidy (2014).Effect of diet supplemented with pumpkin (Cucurbitamoschata) and black seed (Nigella sativa) oils on performance of rabbits: 1- Growth performance, blood haematology and carcass traits of growing rabbits. Rep. Opinion, 6: 52-59.

Gornal A.G.; C.J. Bardawill and M.M. Divid (1949).Determination of plasma protein by means of the biurent reaction. J. Biol. Chem., 177: 751.

Gidenne, T. (2000).Recent advance in rabbit nutrition : Emphasis on fibre requirements. World Rabbit Science, 8:23-32.

Higa T.(1993). Revolution for helping world. Sukjai publishing, Bangkok.; 199.

Higa, T. (2002). Effective microorganisms: A Holistic technology for human kind. Regional workshop on Utilization of effective Micro-Organsms (EM).Ministry of Agriculture, Egypt, March.

Ibrahim, S. A.; Nematallah, G.M. Ali; A.I. El-Faham; M.E. Mohamed and E.M. Khalifa (2013). Effect of date palm waste on performance, carcass characteristics and economic efficiency of Gemaza growing chicks. Egyptian J. Nutrition and Feeds, 16 (2) 309-318.

Linzell, J.L.; M. Peaker and J.C. Taylor (1972).The effects of prolactin and oxytocin on milk secretion and on the permeability of the mammary epithelium in the rabbit. J. Physiol., 253:547.

Lukefahr, S.; W.D Hohenboken, P.R. Cheeke and N.M. Patton (1983).Characterization of straightbred and crossbred rabbits for milk production and associative traits. J. Anim. Sci., 57: 1100-1107.

Maertens, L. (2009). Possibilities to reduce the feed conversion in rabbit production . In Proc.: Giornate di Coniglicoltura ASIC Forli, Italy, April 2-3, pp. 1-10. 
Mahmoud, E.A.A. (2013). Studies on some factors affecting doe, buck and litter performance in white New Zealand rabbit under Egyptian condition. Benha Veterinary Medical Journal, 25(2): 1-12.

Mohamed, A.H.; Fatma, T.F.Abd-Ghany and A.A.S Mahgoup(2016). Influence of supplementation of some trace minerals in form of nanoparticles on productive and reproductive performance of rabbit. Egyptian J. Nutrition and feeds, 19 (2):pp 325-335.

Reitman, S. and S. Frankel (1957). Determination of GOT and GPT Amr. J. Clin. Path., 28:56-63.

Richmond, W. (1973).Determination of cholesterol.Clin. Chem., 19:1350.

SAS (2004).User's guide.Statistic. Version 9.SAS Inst. Cary, N.C. Releigh USA.

Schirmeister, J. (1964).Determination of creatinine.Dtsch. Med Wschr., 89:1940.Steven Lukefapor, W.D.; W.D. Hohenboken; P.R. Cheeke; N.M. Patton and W.H. Kennick (1981).Carcass and meat characteristics of Flemish giant and New Zealand White purebred and terminal cross rabbits. Journal of Applied Rabbit Research, 4 (3): 66-72.

Shahin, G.F. A.A. Mahrous; M.A. Abdel-Latif and A.A. El-Giziry (2012).Effect of feeding corn stover silage on growth and reproduction performance of buffalo heifers.Egyptian J. Nutrition and Feeds, 15 (1) special issue:17-27.

Soliman, A.Z.M.; M.A.F. El-Manylawi; Fatma G. Ahmed; Fatma T.F. Abd- El Ghany (2012). Reproductive performance of New Zealand white rabbit does fed on diets containing corn distiller's dried grains with soluble. $3^{\text {rd }}$ Mediterranean Poultry Summit and $6^{\text {th }}$ International Poultry Conference, 26 -29 March, Alexandria, Egypt.

Szendro, E., M. Gyovai, E. Biro-Nemeth, I. Radnai, Zs. Matics, Zs Nagy I. and Zs. Szendro (2002). Effect of birth weight, milk supply status and feeding system on the mortality of suckling and growing rabbits. In Proc.: 3rd Sci. Conf. Rabbit Prod. in Hot Climates, 8-11October, 2002, Hurghada, Egypt, pp. 401-407.

Van Socest, P.J. (1982). Nutritional Ecology Of Ruminant $O$ and B Books. Inc., Corvallis, Oredon. 112: 126-127.

Villas-Boas, S.G.; E. Esposito and D.A. Mitchell (2002).Microbial conversion of lignocellulosic residues for production of animal feeds. Anim. Feed Sci. and Techn., 98:1-2. 
Xiccato, G.; A. Trocino; A. Sartori and P.I. Queaque (2004). Effect of parity order and litter weaning age on the performance and body energy balance of rabbit does. Livest. Prod. Sci., 85: 239-251.

Zollner, N. and K. Kirsch (1962).Determination Of Total Lipids In Blood By Colorimetric Method. Z. Ges. Exp. Med., 135: 454- 454.

\title{
الأستجابة الأنتاجية والفسيولوجية للأمهات لأرانب النيوزيلاندى الأبيض

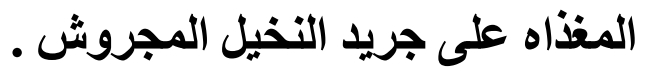

\author{
ولاء عطية سلامة ـ عنايات حسن أبو العزايم

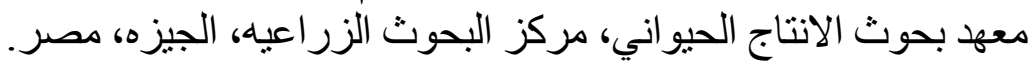

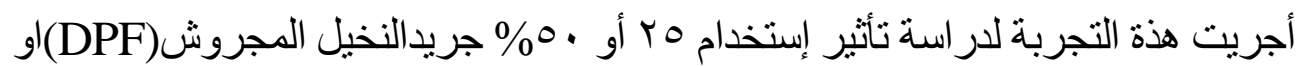

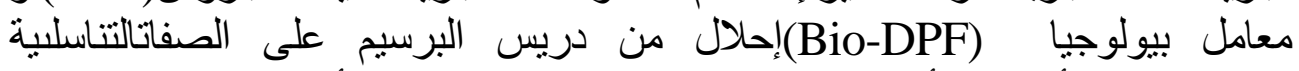

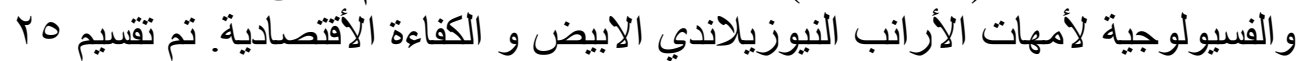

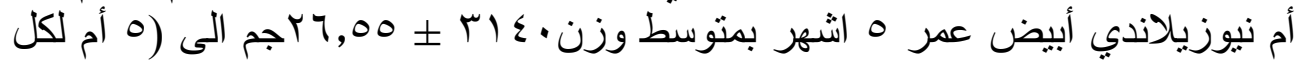

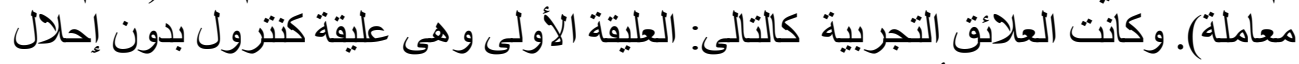

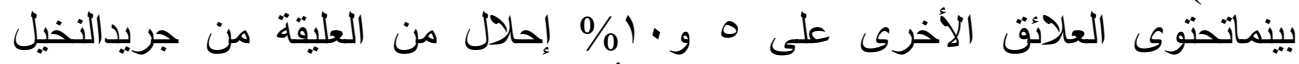

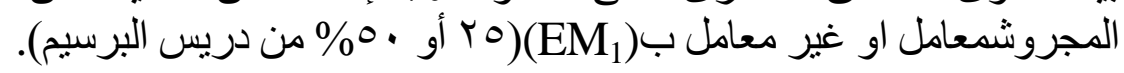
يمكن تلخيص النتائج كما يلى الئ:

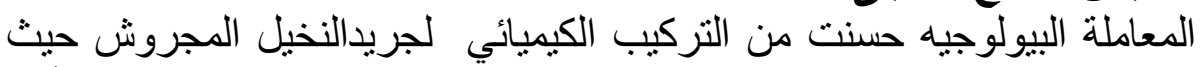

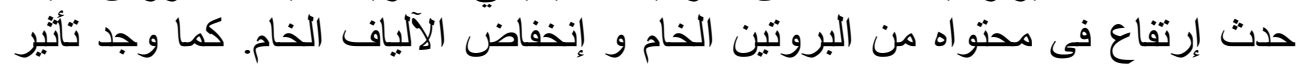

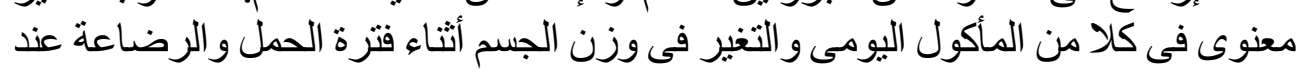

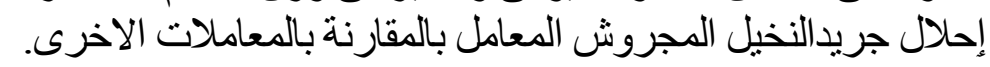

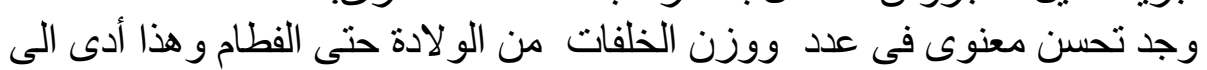

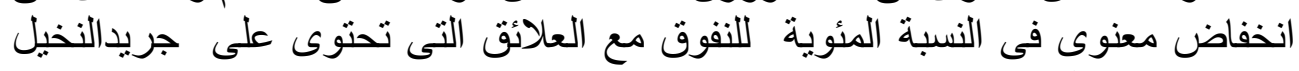

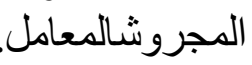
وجود تحسن معنوى فى كمية اللبن عند تغذية الأرانب على علائق تحتوى على

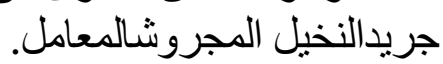




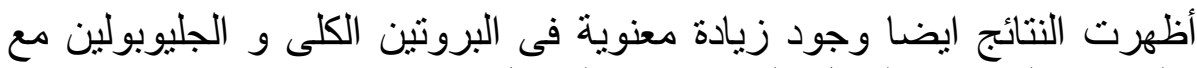

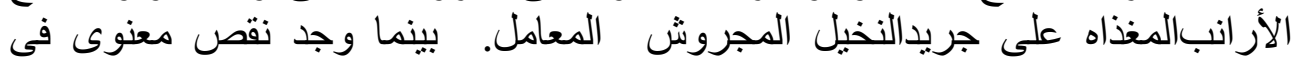

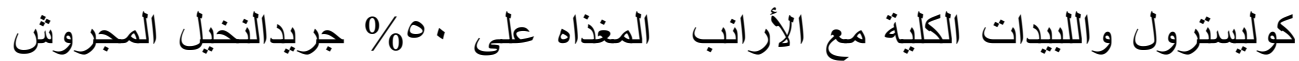

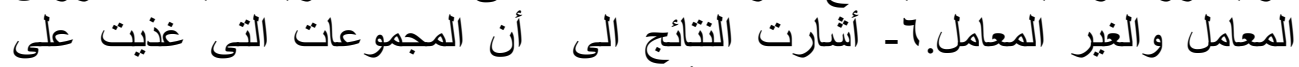

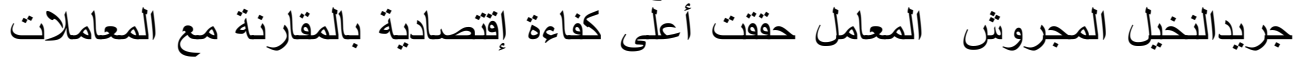

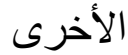

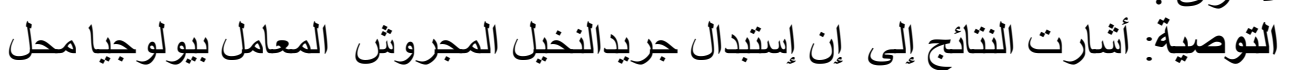

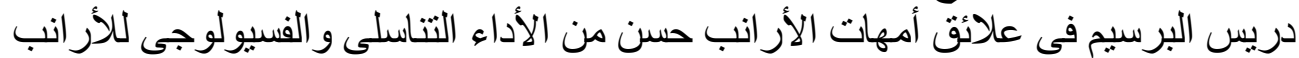
بلأضافة الى تحسين الكفاءة الأقتصادية الكئ.

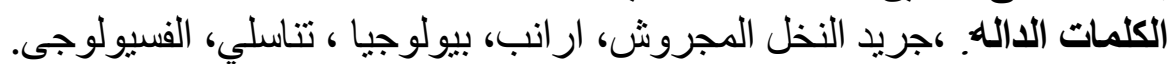

